\title{
Expolinear model on soybean growth in Argentina and Brazil
}

\author{
Modelo expolinear na cultura da soja cultivada na Argentina e no Brasil
}

\author{
Adriana Elisabet Confalone ${ }^{\mathrm{I}}$ Marcos Silveira Bernardes ${ }^{\text {II }}$ Luiz Claudio Costa ${ }^{\text {III }}$

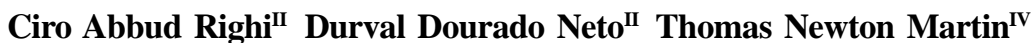 \\ Paulo Augusto Manfron ${ }^{\mathrm{V}}$ Carlos Rodrigues Pereira ${ }^{\mathrm{VI}}$
}

\section{ABSTRACT}

Predicting crop growth and yield with precision are one of the main concerns of the agricultural science. For these purpose mechanistic models of crop growth have been developed and tested worldwide. The feasibility of an expolinear model for crop growth was evaluated on predicting growth modification on soybean (Glycine max L. Merrill) of determined and undetermined growth cultivars, submitted to water restrictions imposed on different phenological stages. An experiment was carried out in Azul/Argentina and in Viçosa/ Brazil during the growing seasons (1997/1998, 1998/1999 and 2002/2003). The expolinear model was adjusted to the dry-matter data obtained from each treatment. The model showed sensibility of $R_{m}$ (maximum relative growth rate of the culture - $g g^{-1}$ day $^{-1}$ ) to variation in air temperature; of $C_{m}$ (maximum growth rate of the culture $-\mathrm{g} \mathrm{m}^{-2}$ day $^{-1}$ ) to solar radiation and of $T$ (lost time -day) to water stress. $C_{m}$ values were higher without water restriction presenting, in both countries, a direct correlation with solar radiation. Without water restrictions, $R_{m}$ values were lower when the average air temperature during the cycle was lower. It was observed that under water stress the culture had a bias to present higher $R_{m}$ values. $T_{b}$ was lower in the irrigated treatments than in those with water deficits. The analysis of the outputs clearly shows the feasibility of the expolinear model to explain the differential growth rates of soybean as a consequence of climatic conditions.

Key words: water deficit, solar radiation, temperature, phenological phase.

\section{RESUMO}

Prever o crescimento e a produtividade das culturas com precisão é uma das principais preocupações das ciências agrícolas. Com esse propósito, modelos mecanísticos de crescimento de culturas têm sido desenvolvidos e testados. A adequação do modelo expolinear de crescimento de culturas foi avaliada para prever as modificações de crescimento de cultivares de soja (Glycine max L. Merrill) de crescimento determinado e indeterminado, submetidas a déficit hídrico em diferentes estádios fenológicos. Um experimento foi conduzido em Azul/Argentina e outro em Viçosa/Brasil durante as estações de cultivo (1997/1998, 1998/1999 e 2002/2003). O modelo expolinear foi ajustado aos dados de fitomassa seca obtidos de cada tratamento. O modelo apresentou sensibilidade do parâmetro $R_{m}$ (taxa máxima de crescimento relativo da cultura $g g^{-1}$ day $\left.^{-1}\right)$ à variação na temperatura do ar; do parâmetro $C_{m}$ (taxa máxima de crescimento da cultura $-\mathrm{g} \mathrm{m}^{-2}$ day $^{-1}$ ) à radiação solar; e do parâmetro $T_{b}$ (perda em tempo - dias) ao estresse hídrico. Os valores de $C_{m}$ foram maiores sem restrições hídricas, apresentando, em ambos os países, uma correlação direta com a radiação solar. Sem restrições hídricas, os valores de $R_{m}$ foram menores quando a temperatura média do ar durante o ciclo foi menor. Sob estresse hídrico, a cultura mostrou uma tendência a apresentar valores de $R_{m}$ maiores. Os valores de $T_{b}$ foram menores nos tratamentos irrigados e maiores nos tratamentos com deficiência hídrica. A análise dos resultados mostrou claramente a capacidade do modelo expolinear para simular as diferentes taxas de crescimento da cultura da soja como uma consequência das condições climáticas.

Palavras chave: déficit hídrico, radiação solar, temperatura, fase fenológica.

\footnotetext{
'Universidad Nacional del Centro de la Provincia de Buenos Aires, Facultad de Agronomía, CC 47, 7300 Azul BA, Argentina.

"Escola Superior de Agricultura “Luiz de Queiroz” (ESALQ), Universidade de São Paulo (USP), Piracicaba, SP, Brasil.

IIIDepartamento de Engenharia Agrícola, Universidade Federal de Viçosa (UFV), Viçosa, MG, Brasil.

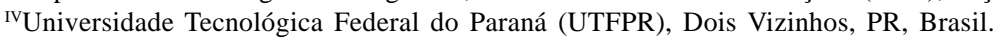

vDepartamento de Fitotecnia, Universidade Federal de Santa Maria (UFSM), Santa Maria, RS, Brasil.

VIDepartamento de Ciências Ambientais, Instituto de Florestas, Universidade Federal Rural do Rio de Janeiro (UFRRJ), 23890-000,

Seropédica, RJ, Brasil. E-mail: carlosrodriguespereira@yahoo.com.br. Autor para correspondência.
} 


\section{INTRODUCTION}

Soybean (Glycine max Merrill L.) has emerged as one of the most important agricultural products of Argentina and Brazil. In these countries, due to their land extension and climatic conditions, it is very common that soybean grows under water shortage during at least one period of its season. The water deficit consequence is even more significant when the culture is in the reproductive phase. The flowering of determinate growth varieties is specially affected, while those of undetermined growth varieties which are more common in the centre of the Buenos Aires province, the phenological phase of the grain filling is more affected by the water shortage (CONFALONE et al., 2001).

Many attempts have been made to describe growth and yield of the cultivated plants as a consequence of the environmental conditions. At first, models were a mere adjustment on the dry-matter $\mathrm{x}$ time graphics. Later on, statistical knowledge advances and increasing computer capacity and availability led to the development of more complex methods (MONTEITH, 1977; STRECK, 2004). These studies have contributed to better understand the connection between growth and development of the plants related to environmental variables, such as: air temperature; precipitation and solar radiation. Despite its application under field conditions, it is submitted to great variations (PROCÓPIO et al., 2003; CONFALONE et al., 2010).

The introduction of mechanistic simulation models of plants growth was an important advance to study the relationship between plants and environmental conditions. These models to explain the mechanism of the whole system. Therefore, their parameters have a physiological meaning and give the possibility to obtain a model by the mean of dry matter accumulation on time differential (dW/dt), thus making essential the definition of variables that determine the growth rate of the culture. The expolinear model is simple and mechanistic, allowing monitoring the total dry matter weight evolution of a culture over time (GOUDRIAAN \& MONTEITH, 1990). Later on, GOUDRIAAN (1994) and GOUDRIAAN \& VAN LAAR (1994) improved the model. This model (equation 1) was derived from a base of functional relations of leaf area expansion, solar radiation interception and dry matter production: $\mathrm{W}(\mathrm{t})=\mathrm{C}_{\mathrm{m}} / \mathrm{R}_{\mathrm{m}} \cdot \ln \left\{1+\exp \left[\mathrm{R}_{\mathrm{m}} \cdot\left(\mathrm{t}-T_{\mathrm{b}}\right)\right]\right\}(1)$, where, $\mathrm{W}(\mathrm{t})=$ total dry-matter $\left(\mathrm{g} \mathrm{m}^{-2}\right) ; \mathrm{C}_{\mathrm{m}}=$ maximum growth rate of the culture $\left(\mathrm{g} \mathrm{m}^{-2}\right.$ day $\left.^{-1}\right) ; \mathrm{R}_{\mathrm{m}}=$ maximum relative growth rate of the culture $\left(\mathrm{g} \mathrm{g}^{-1} \mathrm{day}^{-1}\right) ; \mathrm{t}=$ time (day) after seedling emergency (DAE); $\mathrm{T}_{\mathrm{b}}=$ lost time (day), moment when the culture changes from exponential to linear growth, or when the canopy closes.

The basic conception of the expolinear model is that the growth rate of a culture is proportional to the intercepted radiation and that the plant growth takes place in two different phases. In the first one exponential - the growth rate rises from a very small figure, at the beginning of the cycle, to a maximum value $\left(C_{m}\right)$ reached after $T_{b}$. In this phase, the land cover is at its minimum, the growth of the culture occurs in isolated plants without mutual shading and its duration varies according to environmental conditions. The second phase is linear and starts when the maximum light interception is reached.

This model has been validated and it is possible to follow the total dry-matter evolution of many cultures. For this purpose, it is necessary to draw dry-matter samples at short intervals from the beginning of the culture cycle up to its end (COSTA et al., 1999; LEE et al., 2003; LYRA et al., 2003). A more intensive utilization requires the evaluation of different cultures growing under contrasting environmental conditions. The objective of this research was to test how expolinear model fits the soybean growth under diverse levels of water deficits at different phenological phases.

\section{MATERIAL AND METHODS}

The experimental patches were located at the field experimental area of Facultad de Agronomía de Azul in Azul, Province of Buenos Aires - Argentina ( $36^{\circ} 45^{\prime} \mathrm{S}$; 59 $59^{\circ} \mathrm{W}$; $132 \mathrm{~m}$ above the sea level) during the growing seasons of 1997/1998 and 2002/2003. The area was plain with Typic Argiudoll soil with high content of organic matter. The cultivars of undetermined growth were sowed with 29 plants per square meter in the last week of november: Asgrow 4656 and Don Mario 4800 in the first and second growing season respectively. In Brazil the determined cultivar Capinópolis was tested in the experimental field area of Vila Chaves, belonging to the Universidade Federal de

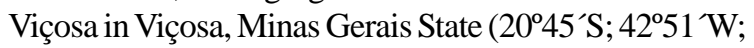
$651 \mathrm{~m}$ above sea level).The sown density was of 20 plants per square meter on December $15^{\text {th }}$ during the 1997/1998 and 1998/1999 growing seasons. The soil was identified as an Inceptic Haplustalf.

The experimental designs were organized in four random complete blocks in a split plot design in both countries, Brazil and Argentina., The main treatment was the water restriction conditions and the secondary one, the sample interval throughout the life cycle of the culture. During the cycle, the plots were covered with a transparent polypropylene sheet 
mounted on a removable structure. Around each treatment plot, a $10 \mathrm{~cm}$ high steel plate was installed to avoid the entrance of runoff.

The soybean's phenological phases were determined using the classification of FEHR \& CAVINESS (1977). The end of the vegetative phase was identified when $50 \%$ of the plants showed at least one open flower (R1). The change of reproductive phase to grain filling was determined by the occurrence of $50 \%$ of plants with seeds of at least $3 \mathrm{~mm}$ length and located in one of the four superior knots at the main stem (R5).

The experimental treatments during the growing season 1997/1998, in Argentina, were: $a$ irrigated during the full season $\left(\mathrm{I}_{\mathrm{AR}}\right)$, keeping the soil near its field capacity; $b$ - without irrigation within reproductive phenological phases $\mathrm{R} 1$ and $\mathrm{R} 4$ included, $\left(\mathrm{NIR} 1_{\mathrm{AR}}\right)$ and; $c$ - without irrigation within reproductive phenological phases R5 and R6 included, (NIR2 $2_{\mathrm{AR}}$ ). During the growing season 2002/2003 the experimental treatments were: $a$ - with soil kept near its field capacity $\left(\mathrm{II}_{\mathrm{AR}}\right)$ and; $b$ - without irrigation $\left(\mathrm{D}_{\mathrm{AR}}\right)$.

During the 1997/1998 growing season, the treatments, in Brazil, were: $a$ - irrigated during full season (I ), keeping the soil near its field capacity; $b$ - without irrigation within vegetative phenological phase V1 and Vn (NIV ); $c$ - without irrigation within the reproductive phenological phases R1 and R4 included, (NIR1 ). During the 1998/1999 growing season, the treatments were: $a$ - irrigated during full season (II ), keeping the soil near its field capacity; $b$ - without irrigation within vegetative phenological phase V1 and Vn (NIVb ); $c$ without irrigation within reproductive phenological phases R1 and R4 included, (NIR1b ).

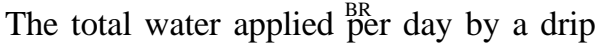
system, in Argentina, was calculated using the PENMANFAO equation for reference evapotranspiration and applying a crop coefficient to estimate the soybean evapotranspiration (DOORENBOS \& PRUIT, 1977). In Brazil, the evapotranspiration was calculated by using a Class A Pan and a micro-aspersion system was used for irrigation. Meteorological data were obtained from a micrometeorological weather station near the experimental area in Argentina as well as in Brazil. In both countries, ten plants were sampled every two days from each plot until the $40^{\text {th }}$ day after emergence. After this period, the interval between samples was extended to seven days. Plants were dried in a ventilated heater at $75^{\circ} \mathrm{C}$ until constant weight measured by a precision scale. The calculated mean dry weight of the ten plants was used to adjust the model.

The expolinear model was adjusted using the Origin 6.0 (Origin Lab ${ }^{\circledR}$ Data Analysis and Graphing
Software) software, obtaining the values of $\mathrm{R}_{\mathrm{m}}, \mathrm{C}_{\mathrm{m}}$ and $\mathrm{T}_{\mathrm{b}}$ that were estimated with its respective standard deviations and determination coefficients between measured and estimated dry-matter.

\section{RESULTS AND DISCUSSION}

At table 1 (Argentina) it is possible to observe the weather data of global solar radiation, precipitation and mean air temperature in growing seasons 1997/1998; 2002/2003 and the decade 19871997 in Azul-Argentina. Comparison of these climate data variations allows to observe the higher solar radiation available during throughout the 2002/2003 growing season, March excepted, being these values higher than the 1987-1997 decade monthly average. During the 1997/1998 growing season, solar radiation and air temperature values remained lower than the decade average, while values of precipitation showed opposite tendency, probably as a result of the 'El Niño' phenomenon. Higher nebulosity and consequent higher rainfall can explain the lower values of solar radiation during the 1997/1998 growing season. On the other hand, the 2002/2003 growing season presented higher solar radiation and air temperature. In that period, precipitation values were lower than the values shown in historical weather data with exception of November.

At the same table 1 (Brazil) it is presented the weather data of global solar radiation, precipitation and air temperature corresponding to the growing seasons 1997/1998; 1998/1999 and the decade 19871997 in Viçosa-Brazil. Within the 1997/1998 period, solar radiation values were lower and air temperature were higher than during 1998/1999. In 1997/1998, the January rainfall, critical for the canopy formation and land cover, was much lower than in 1998/1999 and the decade average. Despite these oscillations, there was good water availability during the tests.

The dry matter and the fitted expolinear models of treatments $\mathrm{I}_{\mathrm{AR}}$, NIR $1_{\mathrm{AR}}$ and NIR2 $2_{\mathrm{AR}}$ for the 1997/1998 growing season can be seen at figure 1 (A, B and $\mathrm{C}$, respectively). In all the treatments, the expolinear model provided a satisfactory explanation of soybean growth variation. Results of the treatments $\mathrm{II}_{\mathrm{AR}}$ and $D_{A R}$ for the 2002/2003 growing season are presented in figures $1 \mathrm{D}$ and $1 \mathrm{E}$, showing a good adjustment of the expolinear model. The values of $C_{m}, R_{m}$ and $T_{b}$ obtained from the adjustment of the model, as well as the determination coefficient $\left(\mathrm{R}^{2}\right)$ shown in table 2 (Argentina). For the 1997/1998 growing season, $\mathrm{R}_{\mathrm{m}}$ varied between 0.121 and $0.163 \mathrm{~g} \mathrm{~g}^{-1}$. day ${ }^{-1}$, and treatment $I_{A R}$ presented the lowest values of $R_{m}$ for both seasons. Comparing all the treatments during 1997/1998, it is 
Table 1 - Monthly average global solar radiation $\left(\mathrm{MJ} \mathrm{m}^{-2}\right.$ day $\left.^{-1}\right)$, precipitation $(\mathrm{mm})$ and air temperature corresponding to the $1997 / 1998$ (97/98) and 2002/2003 (02/03) growing seasons and the 1987-1997 decade (Dec.) in Azul/Argentina - Argentina; and corresponding to the 1997/1998 (97/98) and 1998/1999 (98/99) growing seasons and the 1987-1997 decade (Dec.) in Viçosa/Brazil - Brazil.

\begin{tabular}{|c|c|c|c|c|c|c|c|c|c|}
\hline \multirow[t]{2}{*}{ Month } & \multicolumn{3}{|c|}{ Global Solar Radiation ( $\mathrm{MJ} \mathrm{m}^{-2}$ day $^{-1}$ ) } & \multicolumn{3}{|c|}{ Precipitation (mm) } & \multicolumn{3}{|c|}{ Air Temperature $\left({ }^{\circ} \mathrm{C}\right)$} \\
\hline & $97 / 98$ & $02 / 03$ & Dec. & $97 / 98$ & $02 / 03$ & Dec. & $97 / 98$ & $02 / 03$ & Dec \\
\hline November & 21.4 & 25.43 & 23.3 & 60.7 & 154.7 & 86.7 & 16.1 & 19.3 & 16.9 \\
\hline December & 22.1 & 25.61 & 25.0 & 115.0 & 59.8 & 131.6 & 17.8 & 19.7 & 20.1 \\
\hline January & 24.9 & 27.52 & 24.3 & 187.7 & 42.0 & 142.3 & 20.1 & 22.9 & 21.2 \\
\hline February & 22.0 & 23.53 & 22.7 & 105.3 & 91.8 & 84.1 & 18.1 & 20.6 & 20.5 \\
\hline March & 18.0 & 15.99 & 18.1 & 100.2 & 75.8 & 124.5 & 17.5 & 19.1 & 19.2 \\
\hline \multirow[t]{2}{*}{ Month } & \multicolumn{3}{|c|}{ Global Solar Radiation ( $\mathrm{MJ} \mathrm{m}^{-2}$ day $^{-1}$ ) } & \multicolumn{3}{|c|}{ Precipitation (mm) } & \multicolumn{3}{|c|}{ Air Temperature $\left({ }^{\circ} \mathrm{C}\right)$} \\
\hline & 97/98 & 98/99 & Dec. & $97 / 98$ & 98/99 & Dec. & $97 / 98$ & 98/99 & Dec \\
\hline November & 15.9 & 12.8 & 15.2 & 180.3 & 216.9 & 194.5 & 24.3 & 21.5 & 22.3 \\
\hline December & 16.5 & 15.7 & 15.3 & 206.9 & 113.5 & 242.1 & 24.7 & 23.6 & 23.0 \\
\hline January & 16.3 & 18.1 & 16.6 & 139.8 & 185.5 & 215.8 & 25.0 & 24.6 & 23.6 \\
\hline February & 17.5 & 18.1 & 17.6 & 174.2 & 93.6 & 108.2 & 25.2 & 24.2 & 23.9 \\
\hline March & 15.8 & 16.4 & 15.8 & 102.0 & 280.4 & 131.8 & 24.6 & 23.2 & 23.2 \\
\hline
\end{tabular}

possible to observe that treatments with water deficit presented higher $\mathrm{R}_{\mathrm{m}}$ values (Table 2 - Argentina). This tendency was also found in the 2002/2003 growing season where the cultivar Don Mario 4800 presented higher $\mathrm{R}_{\mathrm{m}}$ value under water stress conditions. At this time, both treatments, irrigated and with water restrictions, showed higher $R_{m}$ values than the previous season (Table 2 - Argentina). These results are in accordance with COSTA et al. (1999) in experiments with determinate growth soybean cultivar under water stress conditions. Not only are the differences observed within the 1997/1998 and 2002/ 2003 growing seasons due to cultivar characteristics, but also to higher solar radiation availability and air temperature in the last season. It is noticeable that the values of maximum relative growth rate of the culture revealed the close fit of the expolinear model before starting the maximum resource capture rate, also confirmed by its low standard error.

The values of $\mathrm{C}_{\mathrm{m}}$ found in both cultivars show sensibility to water deficit during the linear growth phase. During the 1997/1998 growing season significant differences within treatments were observed, although the irrigated treatments during the full season presented a tendency to higher $C_{m}$ values. Among the treatments with water deficit, NIR1 $1_{\mathrm{AR}}$ showed the lowest maximum growth rate of the culture. The water deficit occurred during the first reproductive phases (R1 through R4), when the land cover was still incomplete, probably explains this fact. The maximum growth rate of the culture was remarkably higher during 2002/2003, varying between 29.003 to $28.254 \mathrm{~g} \mathrm{~m}^{-2}$ day $^{-1}$ for the fully irrigated and non-irrigated treatment respectively. During this growing season it was observed a decreasing tendency of $\mathrm{C}_{\mathrm{m}}$ due to water restrictions.

Regarding the time needed for canopy closure and a homogeneous land cover $\left(\mathrm{T}_{\mathrm{b}}\right)$, starting the linear growth, no remarkable differences were found among treatments or years they took place in. No relevant differences of $\mathrm{T}_{\mathrm{b}}$ among treatments were found as the water deficit occurred outside the exponential growth phase. These results clearly show the capacity of soybean to optimize the radiation use under water deficit conditions, as also described by CONFALONE \& DUJMOVICH(1999).

In Brazil the expolinear model fitted well the total dry-matter data in all treatments (Figure 2). As presented in table 2 (Brazil), during 1997/1998 and 1998/ 1999 experiments, there was an excellent adjustment of the model with determination coefficients $\left(\mathrm{R}^{2}\right)$ higher than 0.98 in all treatments.

The maximum relative growth rate $\left(\mathrm{R}_{\mathrm{m}}\right)$ in 1997/1998 was lower in NIR1 $1_{\mathrm{BR}}(0.091)$ and higher in $\mathrm{I}_{\mathrm{BR}}$ (0.117). In 1998/1999, NIR1 $b_{B R}$ exhibited the lowest value (0.095). In general, values of $R_{m}$ were higher in 1998/ 1999 with exception of the treatment $\mathrm{II}_{\mathrm{BR}}$. The values of $\mathrm{R}_{\mathrm{m}}$ were lower for all treatments with some water deficit in 1997/1998 growing season. In 1998/1999, NIVb BR $_{\text {B }}$ ( 0.131 ) presented the highest value of $R_{m}$ followed by $\mathrm{II}_{\mathrm{BR}}(0.108)$ and NIR1b $\mathrm{b}_{\mathrm{BR}}(0.095)$.

Ciência Rural, v.40, n.5, mai, 2010. 

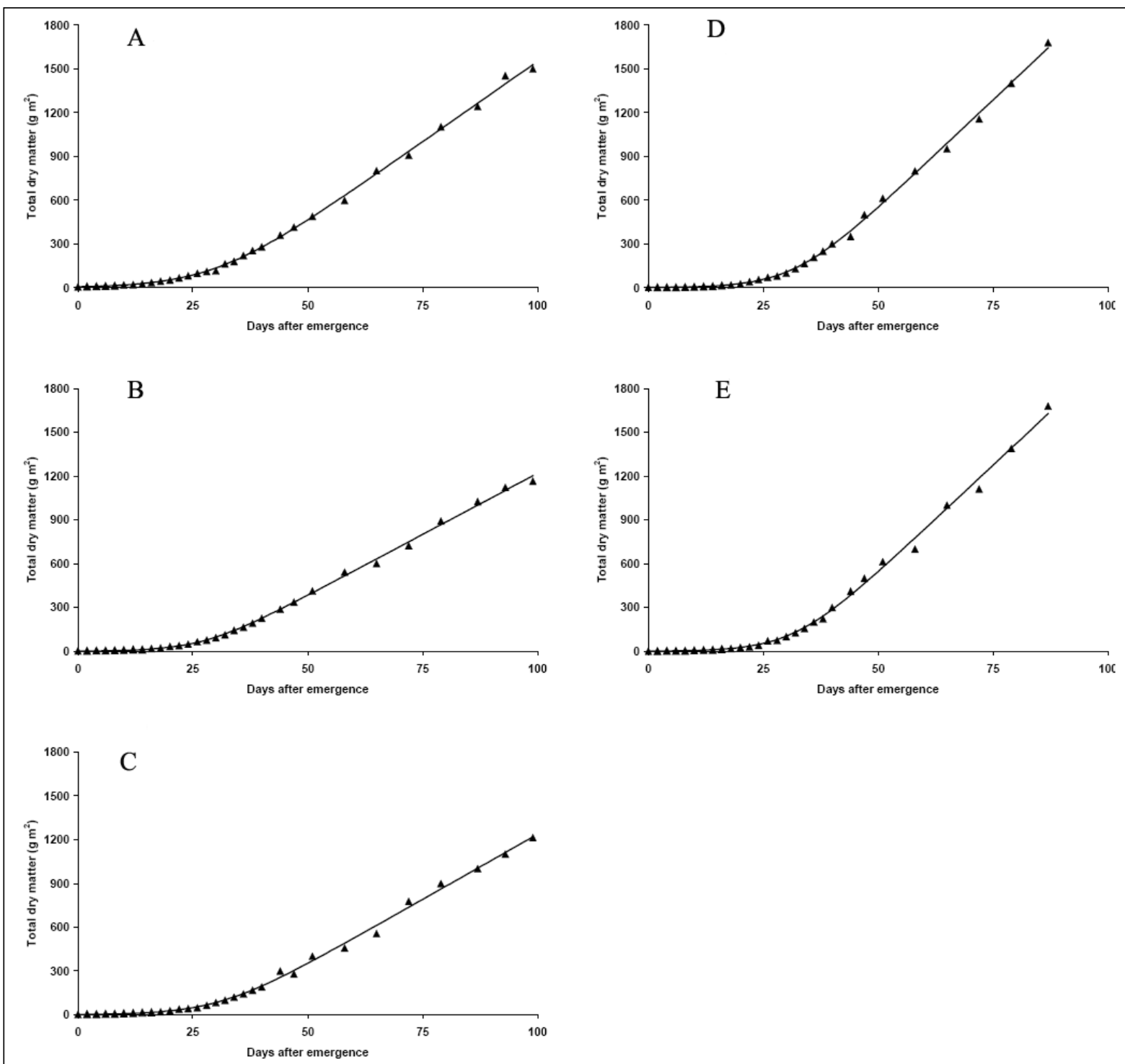

Figure 1 - Expolinear function $(-)$ fitted to the observed values of total dry matter

$-\mathrm{g} \mathrm{m}^{-2}$ ) for soybean (Glycine max Merrill L.) in the 1997/1998 and 2002/2003 growing seasons in Azul City/Argentina - 1997/1998 growing season: A - irrigated during full season (IAR), keeping the soil near its field capacity; B - without irrigation within reproductive phenological phases R1 and R4 (NIR1 ${ }_{\mathrm{AR}}$ ) and; C - without irrigation within reproductive phenological phases R5 and R6 (NIR2 ${ }_{\mathrm{AR}}$ ). 2002/2003 growing season: D - with soil kept near its field capacity $\left(\mathrm{II}_{\mathrm{AR}}\right)$ and $\mathrm{E}$ - without irrigation $\left(\mathrm{D}_{\mathrm{AR}}\right)$.

In $1997 / 1998$ the treatment $\mathrm{NIV}_{\mathrm{BR}}$ presented the highest value of $\mathrm{C}_{\mathrm{m}}$ (25.569), while in the other two remaining treatments its values were close to each other ( $\mathrm{I}_{\mathrm{BR}}$ : 21.980 and $\mathrm{NIR} 1_{\mathrm{BR}}$ : 21.406). In 1998/1999 there was an increase of $C_{m}$ values with better environmental conditions (Table 1 - Brazil). $\mathrm{II}_{\mathrm{BR}}$ presented the highest value (33.172) followed by NIR1 $b_{\mathrm{BR}}$ (26.579) that remained without irrigation after its canopy closure. The lowest value of $C_{m}$ was obtained in NIVb $_{B R}$ (17.377) that remained under water stress during long time in the vegetative phase. The results of 1998/1999 growing season match the theoretical expectation. In the 1997/ 1998 growing season the $C_{m}$ variation among treatments was lower than presented in 1998/1999, with a maximum variation of $16 \%$ among extreme values. In 1998/1999, the variation was $48 \%$. A probable explanation for a lower $C_{m}$ in the treatment $\mathrm{I}_{\mathrm{BR}}$ than in $\mathrm{NIV}_{\mathrm{BR}}$ in 1997/1998 growing season may be attributed to the plastic sheet cover which favoured this treatment in a year of ' $\mathrm{El}$ Niño’ occurrence (1997/1998 season).

The time lost $\left(\mathrm{T}_{\mathrm{b}}\right)$ in 1997/1998 was lower in $\mathrm{I}_{\mathrm{BR}}$ and higher in $\mathrm{NIV}_{\mathrm{BR}}$. The 1998/1999 experiment 
Table 2 - Expolinear model parameters: maximum growth rate of the culture $\left(\mathrm{C}_{\mathrm{m}}-\mathrm{g} \mathrm{m}^{-2}\right.$ day $\left.^{-1}\right)$; maximum relative growth rate of the culture $\left(\mathrm{R}_{\mathrm{m}}-\mathrm{g} \mathrm{g} \mathrm{g}^{-1}\right.$ day $\left.^{-1}\right)$ and; time lost $\left(\mathrm{T}_{\mathrm{b}}\right.$ - days) with their respective standard deviations and determination coefficients $\left(\mathrm{R}^{2}\right)$ obtained from the adjustment of the model and the soybean dry matter data from the 1997/1998 and 2002/2003 growth seasons in Azul/Argentina - ARGENTINA; and from the 1997/1998 and 1998/1999 growth seasons in Viçosa/Brazil - BRAZIL.

\begin{tabular}{|c|c|c|c|c|c|}
\hline Season & Treatment & $\begin{array}{c}\mathrm{C}_{\mathrm{m}} \pm \text { s.e } \\
\left(\mathrm{g} \mathrm{m}^{-2} \text { day }^{-1}\right)\end{array}$ & $\begin{array}{c}\mathrm{R}_{\mathrm{m}} \pm \text { s.e } \\
\left(\mathrm{g} \mathrm{g}^{-1} \text { day }^{-1}\right)\end{array}$ & $\begin{array}{c}\mathrm{T}_{\mathrm{b}} \pm \text { s.e } \\
\text { (day) }\end{array}$ & $\mathrm{R}^{2}$ \\
\hline \multirow[t]{3}{*}{ 1997/1998 } & $\mathrm{I}_{\mathrm{AR}}$ & $21.980 \pm 0.872$ & $0.121 \pm 0.005$ & $29.014 \pm 0.801$ & 0.999 \\
\hline & $\mathrm{NIR} 1_{\mathrm{AR}}$ & $16.749 \pm 0.253$ & $0.163 \pm 0.018$ & $27.230 \pm 0.716$ & 0.999 \\
\hline & $\mathrm{NIR}_{\mathrm{AR}}$ & $17.688 \pm 0.409$ & $0.142 \pm 0.018$ & $30.210 \pm 1.096$ & 0.997 \\
\hline \multirow[t]{2}{*}{$2002 / 2003$} & $\mathrm{II}_{\mathrm{AR}}$ & $29.003 \pm 0.612$ & $0.161 \pm 0.013$ & $31.369 \pm 0.730$ & 0.999 \\
\hline & $\mathrm{D}_{\mathrm{AR}}$ & $28.254 \pm 0.885$ & $0.174 \pm 0.024$ & $30.938 \pm 1.075$ & 0.997 \\
\hline Season & Treatment & $\begin{array}{c}\mathrm{C}_{\mathrm{m}} \pm \text { s.e } \\
\left(\mathrm{g} \mathrm{m}^{-2} \text { day }^{-1}\right)\end{array}$ & $\begin{array}{c}\mathrm{R}_{\mathrm{m}} \pm \text { s.e } \\
\left(\mathrm{g} \mathrm{g}^{-1} \text { day }^{-1}\right)\end{array}$ & $\begin{array}{c}\mathrm{T}_{\mathrm{b}} \pm \text { s.e } \\
\text { (day) }\end{array}$ & $\mathrm{R}^{2} \pm$ s.e \\
\hline \multirow[t]{3}{*}{ 1997/1998 } & $\mathrm{I}_{\mathrm{BR}}$ & $21.980 \pm 0.272$ & $0.117 \pm 0.005$ & $37.325 \pm 0.531$ & 0.999 \\
\hline & $\mathrm{NIV}_{\mathrm{BR}}$ & $25.569 \pm 1.026$ & $0.093 \pm 0.005$ & $46.248 \pm 1.355$ & 0.999 \\
\hline & $\mathrm{NIR} 1_{\mathrm{BR}}$ & $21.406 \pm 2.706$ & $0.091 \pm 0.016$ & $41.085 \pm 4.617$ & 0.987 \\
\hline \multirow[t]{3}{*}{ 1998/1999 } & $\mathrm{II}_{\mathrm{BR}}$ & $33.172 \pm 2.917$ & $0.108 \pm 0.022$ & $44.674 \pm 3.336$ & 0.988 \\
\hline & $\mathrm{NIVb}_{\mathrm{BR}}$ & $17.377 \pm 1.598$ & $0.131 \pm 0.042$ & $36.322 \pm 3.743$ & 0.978 \\
\hline & NIR1b $_{\text {BR }}$ & $26.579 \pm 1.224$ & $0.095 \pm 0.006$ & $48.371 \pm 1.542$ & 0.998 \\
\hline
\end{tabular}

presented NIR1 $b_{B R}$ with the highest value of $T_{b}$, followed by $\mathrm{II}_{\mathrm{BR}}$ and $\mathrm{NIVb}_{\mathrm{BR}}$. In general, $\mathrm{T}_{\mathrm{b}}$ values for the treatments without water deficits in the vegetative phase were lower in the 1997/1998 season - when 'El Niño' phenomenon occurred - probably due to a fast growth of the plants as a result of higher air temperature, leading to lower $\mathrm{T}_{\mathrm{b}}$ values.

In Argentina the environmental data (Table 1) showed a higher monthly solar radiation, lower air temperature and a more homogeneous rain pattern as compared to Brazil. As a general figure, we can verify that $C_{m}$ values were higher without water restriction, presenting in both countries a direct correlation to solar radiation. In both countries, the experiments showed that $\mathrm{C}_{\mathrm{m}}$ has a bias to diminish under water shortage in any period of the soybean cycle.

The sensibility of $R_{m}$ to air temperature variation was confirmed when comparing the Argentina $R_{m}$ values that were lower in the $1997 / 1998$, season with lower air temperature, according to ISHAG and DENNETT (1998). In Argentina and in Brazil, with no water deficit, the $R_{m}$ values were lower when the average air temperature during the cycle was lower. Comparing the values of $\mathrm{R}_{\mathrm{m}}$ among treatments, we can verify in the 1997/1998 growing season, results obtained in Brazil were opposite to those from Argentina; in the $1998 / 1999$ growing season it is possible to observe the same tendency (Table 2). It was observed that under water stress the culture has a bias to present higher $R_{m}$ values. Cultivars of determined growth behaviour showed a great $T_{b}$ variation. In the 1997/1998 growing season $T_{b}$ was lower in the irrigated treatment, as expected. It was not observed the same tendency in 1998/1999 growing season in Brazil neither in Argentina (Table 2).

The expolinear model fitted well the soybean culture of determined and undetermined growth, under variable water stress conditions during its cycle in Argentina and in Brazil. The determination coefficients $\left(\mathrm{R}^{2}\right)$ were higher than 0.98 in all situations (Figures 1 and 2 and Table 2). The greater variations in parameters values observed in Brazil may be attributed to the interference of the polypropylene sheet cover and to the great plasticity of the soybean culture. Possibly, parameters should be adapted as a function of environmental stresses. Studies to link parameters variations to climate should be part of future investigations.

\section{CONCLUSION}

The growth of the soybean culture can be satisfactorily described by the expolinear function, even under very distinct environmental conditions. The 

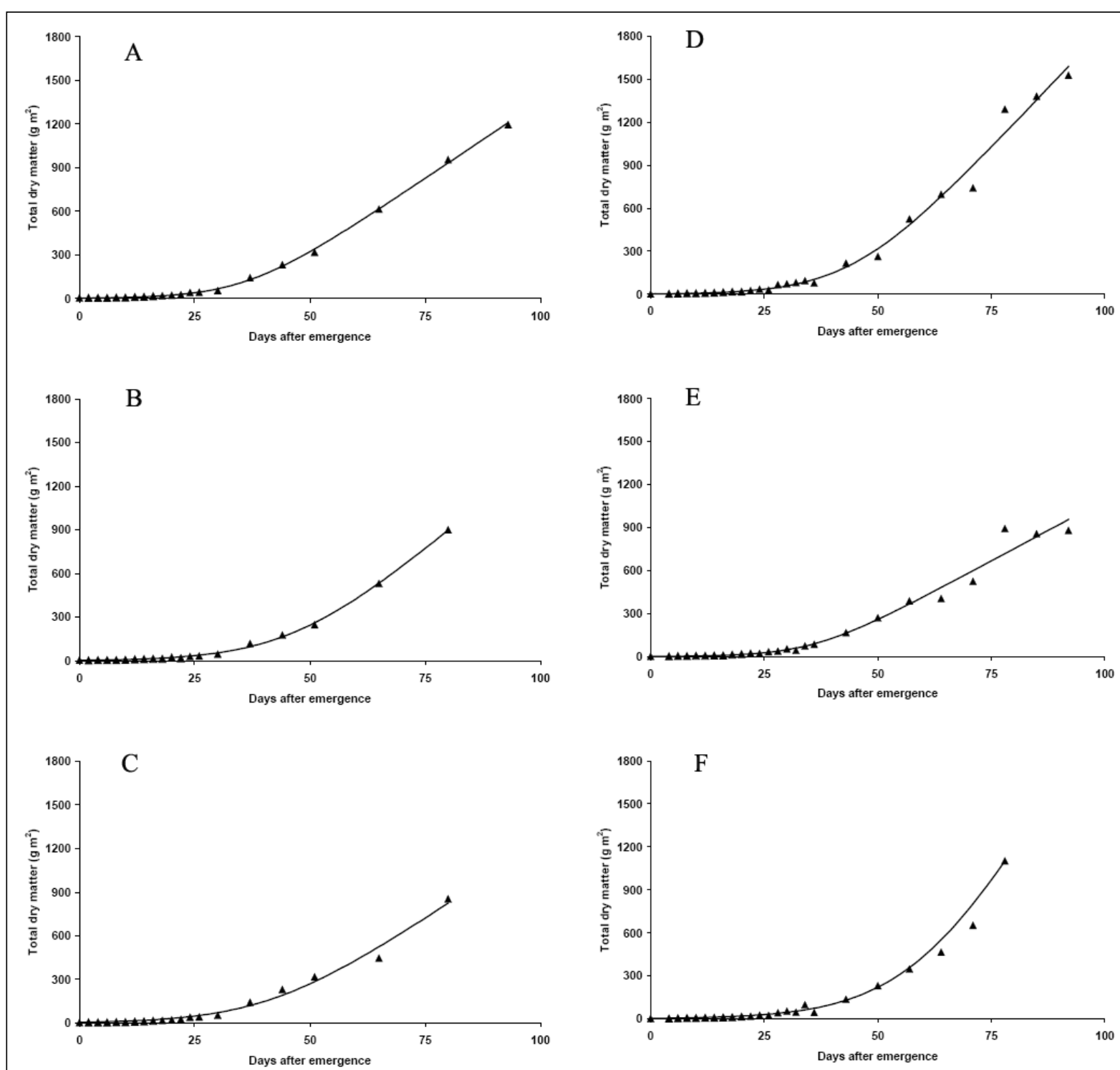

Figure 2 - Expolinear function $(-)$ fitted to the observed values of total dry matter $\left(-\mathrm{g} \mathrm{m}^{-2}\right)$ for soybean (Glycine max Merrill L.) in the 1997/1998 and 1998/1999 growing seasons in Viçosa/Brazil - 1997/1998 growing season: A - irrigated during full season (IBR), keeping the soil near its field capacity; B - without irrigation within vegetative phenological phases V1 and Vn (NIVBR); C - without irrigation within reproductive phenological phases R1 and R4 (NIR1 ${ }_{\text {BR }}$ ). 1998/1999 growing season: D - irrigated during full season $\left(\mathrm{II}_{\mathrm{BR}}\right)$, keeping the soil near its field capacity; $\mathrm{E}$ - without irrigation within vegetative phenological phases $\mathrm{V} 1$ and $\mathrm{Vn}\left(\mathrm{NIVb}_{\mathrm{BR}}\right)$; $\mathrm{F}$ - without irrigation within reproductive phenological phases R1 and R4 (NIR1 $\left.\mathrm{b}_{\mathrm{BR}}\right)$.

model tested fitted well to the collected data, indicating its potentiality as a growth-predicting tool for different soybean cultivars. The model showed a clear sensibility of $R_{m}$ to variation on air temperature; of $C_{m}$ to solar radiation and of $T_{b}$ to water stress. In general, it was possible to verify that $C_{m}$ values were higher without water restriction presenting in both countries a direct correlation to solar radiation. The model was sensible to the both, main (water stress and growth habit) and minor factors (air temperature and solar radiation) that affect soybean growth.

\section{REFERENCES}

CONFALONE, A. et al. Growth, PAR use efficiency, and yield components of field-grown Vicia faba L. under different temperature and photoperiod regimes. Field Crops Research, v.115, n.2, p.140-148, 2010. Available from: <http://dx.doi.org/ 10.1016/j.fcr.2009.10.014> Accessed: jan. 15, 2010. doi: 10.1016/j.fcr.2009.10.014.

Ciência Rural, v.40, n.5, mai, 2010. 
CONFALONE, A.; DUJMOVICH, M. Influência do déficit hídrico sobre a eficiência de utilização da radiação em soja. Revista Brasileira de Agrociência, v.5, p.195-198, 1999.

CONFALONE, A.E. et al. Influencia del déficit hídrico sobre el desarrollo y rendimiento del cultivo de soja en Brasil y Argentina. Agro-Ciencia, v.17, n.1, p.3-8, 2001.

COSTA, L.C. et al. Uso da função Expolinear para analise do crescimento da cultura da soja. Revista Brasileira de Agrometeorologia, v.7, p.213-218, 1999.

DOORENBOS, J.; PRUITT, W.O. Necesidad de agua de los cultivos. Roma: FAO, 1977. 194p.

FEHR, W.R.; CAVINESS, C.E. Stages of soybean development. Ames: Iowa Agriculture Experimental Station, 1977. 12p.

GOUDRIAAN, J. Using the expolinear growth equation to analyze resource capture. In: MONTEITH J.L. et al. (Eds). Resource capture by crops. Nottingham: Nottingham University, 1994. p.99-110.

GOUDRIAAN, J.; Van LAAR, H.H. Modelling potential crop growth processes. Dordrecht: Kluwer Academic Publishers, 1994. 239p.

GOUDRIAAN, J.; MONTEITH, J.L. A mathematical function for crop growth based on light interception and leaf area expansion. Annals of Botany, v.66, 695-701, 1990.
ISHAG, K.H.M.; DENNETT, M.D. Use of the expolinear growth model to analyse the growth of faba bean, peas and lentils at three densities: fitting the model. Annals of Botany, v.82, 497-505, 1998.

LEE, J.H. et al. Using the expolinear growth equation for modelling crop growth in year-round cut chrysanthemum. Annals of Botany, v.92, p.697-708, 2003.

LYRA, G.B. et al. Modelos de crescimento para alface (Iactuca sativa l.) cultivada em sistema hidropônico sob condições de casa-de-vegetação.Revista Brasileira de Agrometeorologia, v.11, n.1, p.69-77, 2003.

MONTEITH, J.L. Climate and the efficiency of crop production in Britain. Philosophical Transactions of the Royal Society of London B, v.281, p.227-294, 1977.

PROCÓPIO, S.O. et al. Desenvolvimento foliar das culturas da soja e do feijão e de plantas daninhas. Ciência Rural. v.33, n.2, p.207-211, 2003. Available from: <http://www.scielo.br/ s c i e l o.ph p ? s c ri p t = s c i_art text \& pid = S 0103 84782003000200005\&lng=en\&nrm=iso > Accessed: jan. 15, 2010. doi:10.1590/S0103-84782003000200005.

STRECK, N.A. A temperature response function for modeling leaf growth and development of the African violet (Saintpaulia ionantha Wendl.). Ciência Rural, v.34, n.1, p.55-62, 2004. Available from: $<$ http://www.scielo.br/scielo.php?script=sci_arttext\&pid=S010384782004000100009\&lng=en\&nrm=iso>. Accessed: jan. 15, 2010. doi: 10.1590/S0103-84782004000100009. 